\section{Psychotherapy and Psychosomatics}

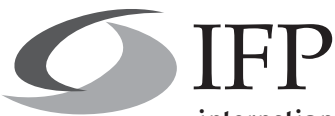

international federation for psychotherapy
Psychother Psychosom 2010;79:63-64

DOI: 10.1159/000261558
Published online: November 26, 2009

\title{
President's Message
}

Dear friends and colleagues

Lester Luborsky has passed away. Born in 1920, he had been one of the great, leading figures in the field of academic psychotherapy for half a century. Those among us who did not have the chance to get to know him in person will remember him not only as the author of the highly cited review of comparative studies of psychotherapies in which he applied the Dodo bird verdict 'Everyone has won and all must have prizes' to the effectiveness of various psychotherapies. Lester Luborsky also developed the concept of the 'core conflictual relationship theme' (CCRT), and made countless other valuable contributions to our field. An obituary will appear in the forthcoming IFP Newsletter which will be downloadable from the IFP Website by end of November 2009.

The upcoming 20th IFP World Congress of Psychotherapy in Lucerne, Switzerland, June 16-19, 2010, is certainly the major focus of our current activities. Both the IFP Board and the scientific program committee are getting increasingly excited about what promises to become a truly memorable conference. Just to give you an idea of the program, there will be a total of six plenary lectures:

- 'Culture and psychotherapy: clinical, theoretical, and philosophical explorations from a worldwide perspective', by WenShing Tseng, Hawaii, President of the World Association of Cultural Psychiatry.

- 'Hearing God: an anthropologist looks at American evangelicals', by anthropologist Tanya Luhrmann, Stanford, Calif., USA.

- 'Psychotherapy: a perspective from Africa', by Merle Friedman, Johannesburg, South Africa.

- 'The neurobiology of psychotherapy', by Lutz Jäncke, Zürich, Switzerland.

- 'Can attachment theory help us understand better what we're doing as psychotherapists?', by Jeremy Holmes, Exeter, UK.

- 'Japanese culture and its influence on children and their family', by Nana Hosogane, Tokyo, Japan.

In addition, the program will feature three debates:

- 'The management of recurrent depression: is drug treatment necessary?', chaired by Jules Angst, Zürich, Switzerland, with Giovanni Fava, Italy and Hans-Jürgen Möller, Germany.

- 'Cultural sensitivity - an eastern and a western perspective?', chaired by Bernhard Strauss, Jena, Germany, with Marvin Goldfried, USA and Sudhir Kakar, India.
- 'The development of the psychotherapeutic professions worldwide', chaired by Norman Sartorius, Geneva, Switzerland, with Gerhard Grobler, South Africa, Philippe Grosbois, France, Fritz Hohagen, Germany, Douglas Kong, Singapore, and Alfred Pritz, Austria.

The Congress website, including the online abstract submission and registration system, is operational as of now, informing you on the progress of our planning: please visit the Congress website at www.ifp-fmpp2010.com, and submit your abstracts. Please also note that the deadline for 'Early Bird' registration at a reduced rate is February 28, 2010.

Our World Congress will be organized by the Foederatio Medicorum Psychiatricorum et Psychotherapeuticorum FMPP (http://www.psychiatrie.ch), which is an umbrella organization that unites the Swiss Societies for Psychiatry and Psychotherapy, both for adults as well as for children and adolescents. The conference is also cosponsored by the World Psychiatric Association WPA. The venue will be the 'KKL Luzern', the Culture and Convention Center Lucerne (http://www.kkl-luzern.ch). This magnificent building was designed by the French architect Jean Nouvel. Built between 1995 and 2000, the KKL ranks today as one of the most spectacular modern buildings in Switzerland. The KKL Luzern is centrally located in the town of Lucerne, directly at the Lake Lucerne and right next to the railway station. The old town center is only a few hundred yards from the KKL Luzern, as is Lucerne's distinctive landmark, the Chapel Bridge.

Under the guidance of Dr. Sylvia Detri Elvira, a member of the IFP Council, the Indonesian Psychiatric Association Section on Psychotherapy will hold their 3rd National Conference on Psychotherapy in Indonesia on May 1-2, 2010. The theme of the conference will be 'The healing power of understanding: its strength and its limitation'. Please feel free to contact Dr. Sylvia Detri Elvira (sylvia.d.elvira@gmail.com) for more information.

The Asian Pacific Association of Psychotherapists APAP keeps being active as well. The Philippine Psychiatric Association will host the 6th APAP conference in Manila, Philippines, in January 2011. Dr. Alma Jimenez and Dr. Maria Imelda Batar, President of the Philippine Psychiatric Association, will be jointly instrumental in organizing this conference.

The Secretarial Office in Zürich is running smoothly under the watchful guidance of Cornelia Erpenbeck. She is responsible

\section{KARGER}

Fax +41 613061234 E-Mail karger@karger.ch www.karger.com (c) 2009 S. Karger AG, Base

0033-3190/10/0791-0063\$26.00/0 
for all administrative matters concerning the IFP and may be contacted at her office should there be any queries. To further optimize the visibility of the IFP, I would like to encourage all our members to introduce a link to the IFP website (http://www.ifp. name) on your respective homepages. We would be happy to do so vice versa. Please feel free to approach Cornelia Erpenbeck in case you need a hand.

IFP-Sponsored Master Classes, Workshops and Seminars. The aim of these events is threefold, namely to help disseminate novel, evidence-based psychotherapeutic approaches, to raise the international profile and recognition of the IFP, and to recruit individual IFP members, thus generating income for the IFP. In 2009, successful workshops were held on 'Positive Psychotherapy' with Professor Nossrat Peseschkian, Germany, and on 'CBT for Eating Disorders' with Professor Chris Fairburn, UK. Another workshop on 'Positive Psychotherapy' with Professor Nossrat Peseschkian will be held in Zurich on February 12-13, 2010. More IFPsponsored master classes, workshops and seminars to follow. For further information, please visit our website at http://www.ifp. name.

Collaboration with Other International Societies. There is an ongoing collaboration with the European Psychiatric Association EPA: Professor Möller, EPA President, and Professor Sartorius, a member of the IFP Council, invited me to be one of the speakers in the Presidential Symposium on ethical issues in psychiatric treatment organized during the forthcoming European Congress of Psychiatry in Munich, February 27 to March 2, 2010. The Presidential Symposium has now become a tradition, regularly dealing with ethical issues related to the theme of the congress. I will be giving a talk on 'Ethical problems related to the use of psychotherapy'.

Finally, as always, all our members, meaning individual members of the IFP as well as individual members of associations who have membership status with the IFP, are offered the IFP's official journal, Psychotherapy and Psychosomatics, at a substantially reduced subscription rate. For details, please contact S. Karger directly at:

\section{S. Karger AG \\ Journals Distribution \\ PO Box \\ $\mathrm{CH}-4009$ Basel (Switzerland) \\ Phone +416130611 11 \\ Fax +4161306 1234 \\ E-Mail karger@karger.com}

Best regards

Prof. Ulrich Schnyder, MD

President IFP

u.schnyder@ifp.name

\section{IFP Board}

www.ifp.name

Prof. Ulrich Schnyder, MD

President IFP

Zurich/Switzerland

u.schnyder@ifp.name

Dr. Alfried Längle, MD, PhD

Vice President IFP

Vienna/Austria

a.laengle@ifp.name

Prof. Franz Caspar, PhD

President-elect

Bern/Switzerland

f.caspar@ifp.name

Prof. Mechthild Neises, MD

Secretary General IFP

Hannover/Germany

m.neises@ifp.name

Dr. Michael Rufer, MD

Treasurer IFP

Zurich/Switzerland

m.rufer@ifp.name

\section{Secretariat IFP}

Cornelia Erpenbeck

University Hospital Zurich

Department of Psychiatry

Culmannstrasse 8

CH-8091 Zurich/Switzerland

Phone +41 442555251

Fax +41 442554408

secretariat@ifp.name 